\title{
ЕКСПЕРИМЕНТАЛЬНА ПЕРЕВІРКА ГІПОТЕЗ ЩОДО ІДЕНТИФІКАЦІЇ ЛЮДИНИ ЗА ЕЛЕКТРОКАРДІОГРАМОЮ
}

\author{
Т. М. Романенко, Л. А. Кізуб \\ Інститут проблем математичних машин і систем НАН України
}

\section{EXPERIMENTAL HYPOTHESES VERIFICATION ABOUT THE IDENTIFICATION OF PERSONALITY BY HIS ELECTROCARDIOGRAM}

\author{
T. M. Romanenko, L. A. Kizub \\ Institute of Mathematical Machines and Systems Problems of NAS of Ukraine
}

Вступ. Питання біометричної ідентифікації є актуальним і останніми роками активно обговорюється у літературі. В проекті «Медгрід» це завдання постало при формуванні метабази даних деперсоналізованих електрокардіограм. Для однозначної ідентифікації пацієнта виникла потреба у виділенні деяких характерних ознак сигналів, що разом із відкритими даними про людину (стать, регіон проживання та рік народження) допоможуть визначити необхідність створення нового запису в базі даних або доповнення того, що вже існує.

Результати та їх обговорення. Стандартна електрокардіограма містить 12 відведень, тобто 12 сигналів. Ці 12 відведень можуть бути перетворені на три ортогональні відведення та розмічені на цикли та елементи циклів за допомогою спеціальних алгоритмів.

Маючи три ортогональні відведення електрокардіограми можна представити іiі у вигляді тривимірного фазового годографа. Кількість точок на цьому годографі достатньо велика. Апроксимувавши фрагмент такого годографа, що відповідає QRS-комплексу, параметричними сплайнами, отримуємо значно меншу кількість точок, що характеризують форму кривої. Для апроксимації можна використати канонічний сплайн або криву Безьє. Приклад апроксимованих QRS-комплексів двох людей наведено на рисунку 1.

Подавши тривимірний фрагмент електрокардіограми як сплайн, по-перше, зменшується кількість точок, що відповідають за їі форму, а, по-друге, отримується інваріантність до афінних перетворень.

(C) Т. М. Романенко, Л. А. Кізуб

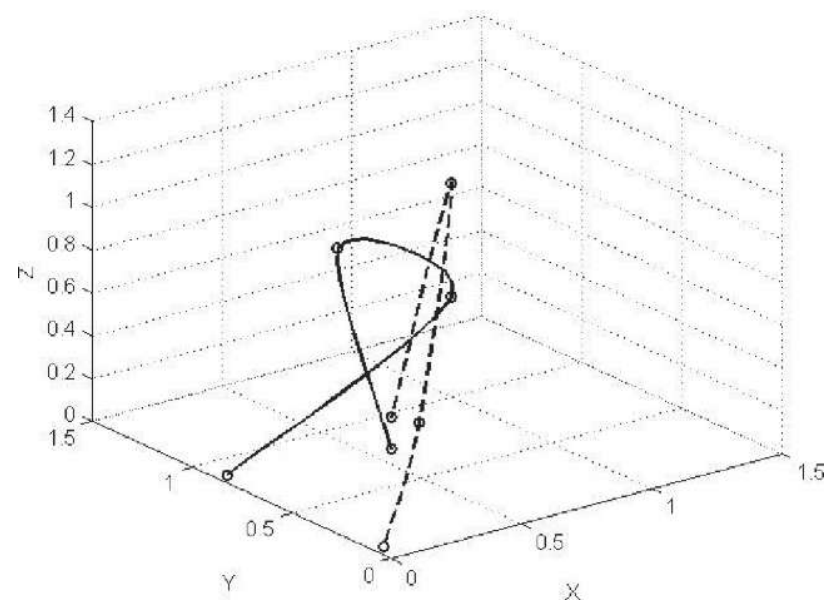

Puc. 1. Результати апроксимації електрокардіограм у трьох відведеннях двох людей.

Окрім стандартної електрокардіограми на 12 відведень існує також електрокардіограма на 6 відведень. У цьому випадку для побудови тривимірної кривої нами використано перші три відведення. Результати апроксимації і подальшої класифікації виявились не гіршими за описані вище.

Висновок. Експериментально перевірено гіпотезу щодо ідентифікації людини за електрокардіограмою. Рішення про належність електрокардіограми до одного 3 класів приймається за результатами порівняння координат точок, що відповідають за форму апроксимуючого сплайна. Для класифікації можна використати відомі статистичні методи або нейромережу. Через те, що реєстрація електрокардіограми у 6 відведеннях зручніша для пацієнта, а також немає потреби у додатковому попередньому перетворенні в ортогональні відведення, цей варіант можна вважати кращим. 